\title{
SIMIPA MODUL ORANG TUA SEBAGAI MEDIA PEMANTAUAN PERKULIAHAN MAHASISWA OLEH ORANG TUA/WALI
}

\author{
${ }^{1}$ Ardiansyah, ${ }^{2}$ Habibi, ${ }^{3}$ Dwi Sakethi, ${ }^{4}$ Anie Rose Irawati \\ 1,2,3,4 Jurusan Ilmu Komputer, FMIPA, Universitas Lampung. \\ e-mail:1ardiansyah@fmipa.unila.ac.id, 2habibi.ilyas@gmail.com, \\ 3ketimbangora@gmail.com, ${ }^{4}$ anie rose@gmail.com
}

\begin{abstract}
The quality of students is one measure of the success of an education system. Qualified students must be supported by many factors, especially support from those closest to them who can increase student morale. Parents / guardians are among the people closest to the students. Parents / guardians should be able to monitor their children's lecture activities, so that the parents / guardians are able to provide appropriate direction and enthusiasm for their children. However, currently there is no special media that provides access to detailed lecture data, so that many students cover their lecture activities which will have an impact on the quality of the students themselves. Therefore, this study develops SIMIPA parent modules as a solution to these problems. SIMIPA Parent Module is an Android-based application as a medium for monitoring student lecture activities by parents. This application provides access to student lecture information that can be seen through the parents' account. This application development uses the Scrum method. Application testing in this study uses user acceptance testing (UAT). The Parent Module SIMIPA application is already in the category of being accepted by prospective users with an average score of 4.12 (satisfactory).
\end{abstract}

Keyword: education, scrum, SIMIPA Parent Module, user acceptance testing (UAT)

\begin{abstract}
Abstrak
Kualitas mahasiswa merupakan salah satu tolak ukur suksesnya suatu sistem pendidikan. Mahasiswa yang berkualitas harus didukung oleh banyak faktor, terutama dukungan dari orang-orang terdekat yang dapat meningkatkan semangat mahasiswa. Orang tua/wali merupakan salah satu orang yang paling dekat dengan mahasiswa. Seharusnya orang tua/wali dapat memantau kegiatan perkuliahan anaknya, sehingga orang tua/wali tersebut mampu memberikan arahan yang sesuai dan semangat terhadap anaknya. Namun, saat ini tidak ada media khusus yang menyediakan akses data perkuliahan secara detail, sehingga banyak mahasiswa yang menutupi kegiatan perkuliahannya yang akan berdampak pada kualitas mahasiswa itu sendiri. Oleh sebab itu, penelitian ini mengembangkan SIMIPA modul orang tua sebagai solusi terhadap permasalahan tersebut. SIMIPA Modul Orang Tua merupakan aplikasi berbasis Android sebagai media pemantauan kegiatan perkuliahan mahasiswa oleh orang tua. Aplikasi ini memberikan akses informasi perkuliahan mahasiswa yang dapat dilihat melalui akun orang tua. Pengembangan aplikasi ini menggunakan metode scrum. Pengujian aplikasi dalam penelitian ini menggunakan user acceptance testing (UAT). Aplikasi SIMIPA Modul Orang Tua sudah masuk kategori diterima oleh calon pengguna dengan score rata-rata 4.12 (memuaskan).
\end{abstract}

Kata kunci: pendidikan, scrum, SIMIPA Modul Orang Tua, user acceptance testing (UAT) 


\section{PENDAHULUAN}

Pendidikan merupakan salah satu pendukung kemajuan suatu negara. Pendidikan tinggi merupakan salah satu lembaga yang bertanggung jawab terhadap kualitas pendidikan. Pendidikan tinggi diharapkan dapat menghasilkan mahasiswa terpelajar yang memiliki semangat tinggi, kreatif, inovatif, dan mandiri. Untuk mencetak mahasiswa yang berkualitas tidak hanya ditentukan oleh perguruan tinggi, tetapi juga harus dari mahasiswa itu sendiri. Orang tua merupakan salah satu faktor yang dapat meningkatkan semangat mahasiswa. Sayangnya, semangat mahasiswa terkadang tidak selalu tinggi. Terkadang mahasiswa berada pada tingkat semangat yang rendah (malas). Saat itu terjadi, pasti akan berdampak pada kualitas perkuliahannya. Mahasiswa tersebut berpeluang mendapatkan nilai yang kurang memuaskan, bahkan berpeluang tidak mengikuti perkuliahan, penelitian, seminar dan kegiatan-kegiatan produktif lainnya. Oleh sebab itu, orang tua harus mengetahui dan memahami kegiatan perkuliahan anaknya sehingga dapat memberikan semangat kepada anaknya. Namun, semakin tinggi pendidikan maka pengawasan orang tua pada proses pendidikan anaknya akan semakin berkurang [1]. Salah satu faktor penyebab yaitu orang tua tidak memiliki akses khusus untuk memantau perkuliahan mahasiswa secara detail. Bahkan terdapat mahasiswa yang sengaja tidak memberitahu informasi secara detail terkait perkuliahannya [2]. Hal tersebut menyebabkan kurangnya pengawasan orang tua dan akan berdampak pada kualitas perkuliahan mahasiswa.

Saat ini, sudah terdapat beberapa sistem pemantauan perkuliahan yang sudah diterapkan di beberapa kampus lain, seperti Sistem Informasi Akademik Berbasis SMS Gateway Pada Fakultas Teknologi Informasi Dan Komunikasi Universitas Semarang yang menyediakan informasi perkuliahan melalui SMS [3]. Selain itu, terdapat juga Sistem Informasi Orang Tua Wali Mahasiswa berbasis Website di Universitas Muhammadiyah Magelang yang menyediakan informasi status KRS, jumlah tagihan dan status pembayaran [2]. Serta, Aplikasi Monitoring Hasil Studi Mahasiswa Teknik Informatika Politeknik Negeri Tanah Laut Berbasis Web Mobile dan SMS Gateway yang menyediakan fitur melihat KHS, status dan rekap kehadiran [4]. Penelitian merupakan penyempurnaan yang diwujudkan melalui pengembangan aplikasi SIMIPA Modul Orang Tua dengan fitur yang lebih lengkap dan penggunaan yang mudah.

SIMIPA (Sistem Informasi Terpadu FMIPA) Modul Orang Tua merupakan aplikasi yang dapat menyajikan data perkuliahan mahasiswa yang dapat diakses oleh orang tua. Aplikasi tersebut dikembangkan berbasis mobile, hal ini disebabkan 94\% populasi di Indonesia dengan rentang usia 16 tahun sampai 64 tahun adalah pengguna smartphone [5]. SIMIPA Modul Orang Tua dikembangkan menggunakan metode scrum dengan pengujian menggunakan metode user acceptance testing (UAT). Metode scrum merupakan metode pengembangan perangkat lunak yang berfokus kepada strategi, fleksibilitas dan kecepatan dalam pengembangan sistem. Dalam pengembangannya akan dibagi menjadi unit-unit yang saling mendukung [6]. Sedangkan metode UAT merupakan pengujian oleh calon pengguna yang bertujuan 
untuk mengetahui tingkat penerimaan calon pengguna terhadap aplikasi yang diuji [7].

\section{METODOLOGI PENELITIAN}

Pengembangan aplikasi pada penelitian ini menggunakan metode scrum. Tahapan pada metode scrum dapat dilihat pada Gambar 1 [8].

\subsection{Product Backlog}

Product backlog adalah daftar kebutuhan yang harus ada dalam suatu produk. Daftar kebutuhan pada penelitian ini dapat dilihat pada Tabel 1.

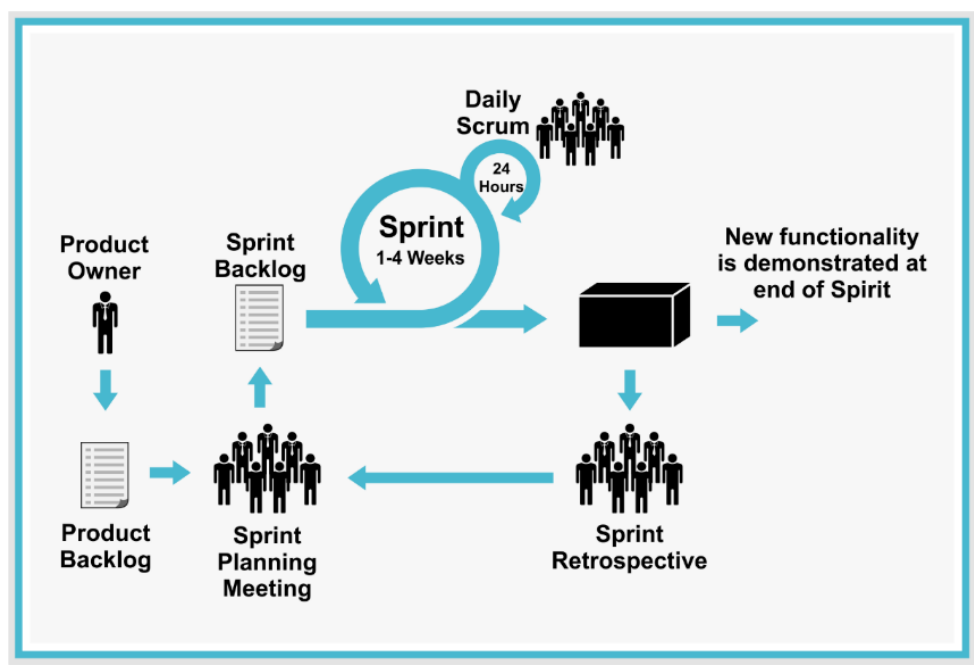

Gambar 1. Tahapan Pengembangan Sistem Menggunakan Metode Scrum.

Tabel 1. Product Backlog Aplikasi SIMIPA Modul Orang Tua

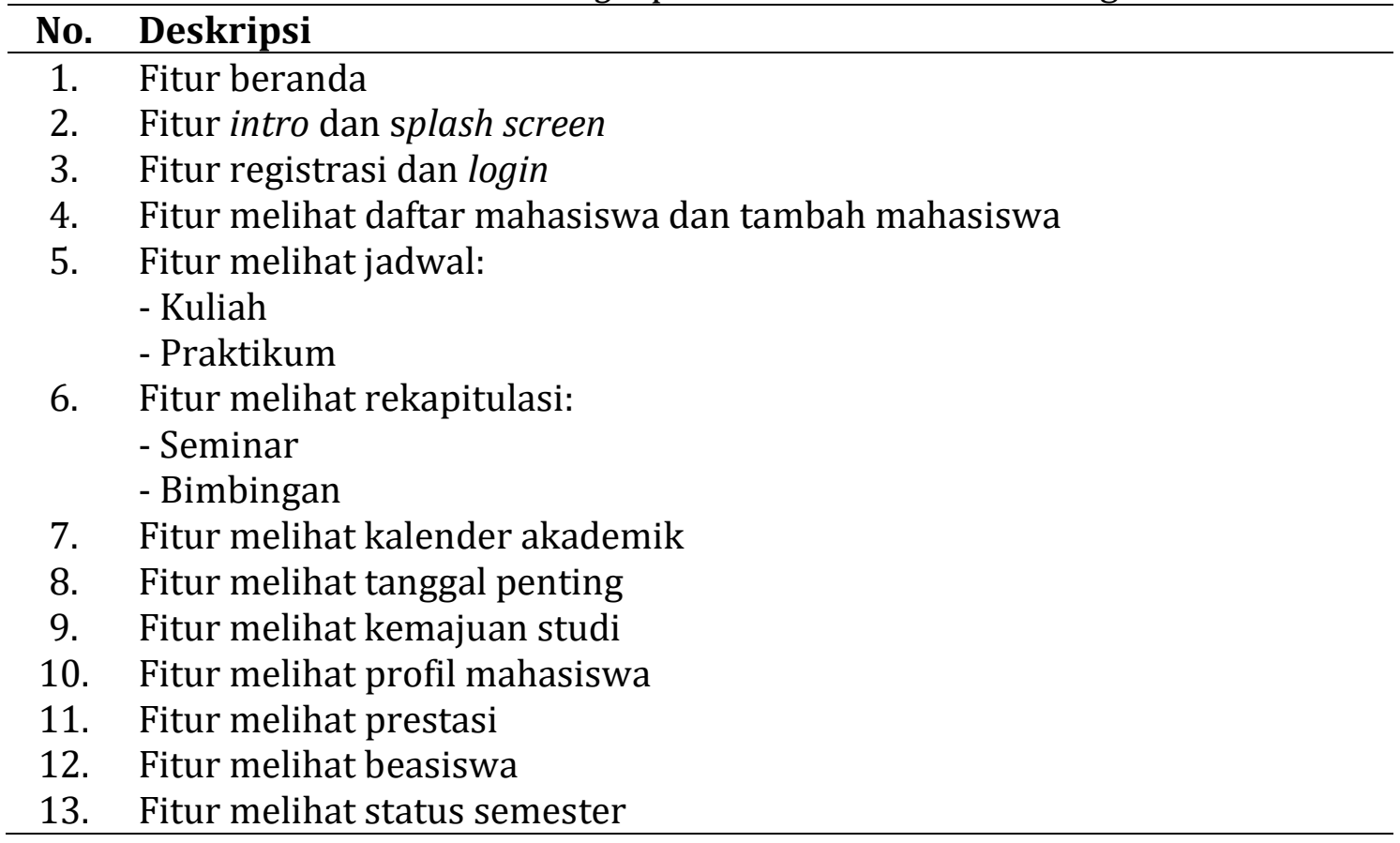


14. Fitur konfirmasi logout

15. Fitur konfirmasi kelola mahasiswa

16. Fitur notifikasi

\subsection{Sprint Planning}

Setiap awal sprint, tim developer akan berdiskusi untuk menentukan sprint backlog. Sprint backlog diambil dari product backlog. Penentuan sprint backlog saat sprint planning memperhatikan kemampuan tim developer dan value product backlog.

\subsection{Daily Sprint}

Saat proses sprint berlangsung, tim developer berkomunikasi dan bekerja sama untuk membahas strategi pengerjaan. Hal ini bertujuan agar sprint yang sedang berjalan dapat terselesaikan dengan baik.

\subsection{Sprint Review}

Pada akhir sprint, tim scrum melakukan sprint review. Pertemuan ini dilakukan untuk membahas apa saja yang sudah dilakukan saat sprint berlangsung. Pada sprint review dibahas apa saja fitur yang sudah sesuai harapan dan fitur yang tidak sesuai harapan.

\subsection{Sprint Retrospective}

Sprint retrospective dilakukan setelah sprint review selesai. Fitur yang tidak sesuai harapan menjadi perbaikan pada tahap ini. Selain itu, tahap ini juga membahas kendala pada sprint yang sudah berlangsung. Hasil retrospective dapat dipertimbangkan untuk merubah strategi saat sprint berikutnya.

\subsection{Pengujian}

Pengujian pada tahap ini menggunakan metode user acceptance testing (UAT) sebagai indikator penerimaan aplikasi oleh calon pengguna aplikasi SIMIPA Modul Orang Tua dengan mengukur tingkat kepuasan calon pengguna. Mekanisme pengujian yaitu memberikan kuesioner kepada calon pengguna (penguji) yang sudah mencoba menggunakan aplikasi SIMIPA Modul Orang Tua

\section{HASIL DAN PEMBAHASAN}

\subsection{Sprint ke-1}

\subsubsection{Sprint Planning}

Hasil sprint planning pada sprint ke-1 dapat dilihat pada Tabel 2.

Tabel 2. Sprint Backlog pada Sprint ke-1

\begin{tabular}{clcc}
\hline No. & Deskripsi & $\begin{array}{c}\text { Estimasi } \\
\text { (Jam) }\end{array}$ & $\begin{array}{c}\text { Tingkat } \\
\text { Kesulitan }\end{array}$ \\
\hline 1. & Use case diagram SIMIPA Modul Orang Tua & 6 & Tinggi
\end{tabular}


2. Activity diagram SIMIPA Modul Orang Tua

15 Tinggi

3. Sequence diagram SIMIPA Modul Orang Tua

$20 \quad$ Tinggi

\subsubsection{Daily Sprint}

Daily sprint pada sprint ke-1 menghasilkan perancangan sistem menggunakan unified modelling language (UML). UML merupakan pemodelan yang ekspresif dan mampu memodelkan semua kebutuhan pengembangan perangkat lunak [9]. Bentuk UML yang digunakan yaitu use case diagram, activity diagram, dan sequence diagram. Use case diagram yang dihasilkan pada daily sprint ke-1 dapat dilihat pada Gambar 2.

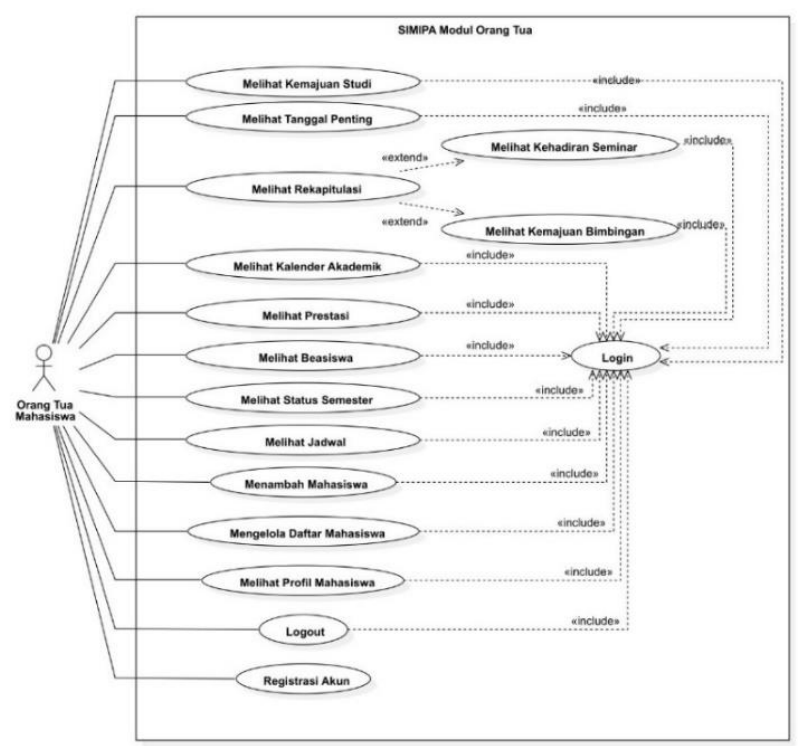

Gambar 2. Use Case Diagram SIMIPA Modul Orang Tua.

\subsubsection{Sprint Review}

Peneliti melakukan presentasi hasil pengerjaan selama sprint ke-1. Hasil dari sprint review yaitu hasil pengerjaan sudah sesuai dengan permintaan dan disetujui oleh scrum master.

\subsubsection{Sprint Retrospective}

Disebabkan hasil pengerjaan sudah sesuai harapan, maka pada sprint ke-1 tidak ada perbaikan yang harus dilakukan.

\subsection{Sprint ke-2}

\subsubsection{Sprint Planning}

Hasil sprint planning pada sprint ke-2 yaitu sprint backlog yang harus diselesaikan pada sprint ke-2. Sprint backlog tersebut dapat dilihat pada Tabel 3.

Tabel 3. Sprint Backlog pada Sprint ke-2 


\begin{tabular}{clcc}
\hline No. & Deskripsi & $\begin{array}{c}\text { Estimasi } \\
\text { (Jam) }\end{array}$ & $\begin{array}{c}\text { Tingkat } \\
\text { Kesulitan }\end{array}$ \\
\hline 1. & Perancangan layout fitur beranda & 3 & Tinggi \\
2. & Perancangan layout fitur intro dan splash screen & 2 & Sedang \\
3. & Perancangan layout fitur registrasi dan login & 2 & Sedang \\
4. & Perancangan layout fitur melihat daftar mahasiswa & 2 & Sedang \\
& dan tambah mahasiswa & & \\
5. & Perancangan layout fitur melihat jadwal: & 3 & Tinggi \\
& - Kuliah & & \\
& - Praktikum & & \\
6. & Perancangan layout fitur melihat rekapitulasi: & 3 & Tinggi \\
& - Seminar & & \\
& - Bimbingan & 2 & Sedang \\
7. & Perancangan layout fitur melihat kalender & 2 & Sedang \\
& akademik & 4 & Tinggi \\
8. & Perancangan layout fitur melihat tanggal penting & 2 & Sedang \\
9. & Perancangan layout fitur melihat kemajuan studi & Sedang \\
10. & Perancangan layout fitur melihat profil mahasiswa & 2 & Sedang \\
11. & Perancangan layout fitur melihat prestasi & 2 & Sedang \\
12. & Perancangan layout fitur melihat beasiswa & 2 & Sedang \\
13. & Perancangan layout fitur melihat status semester & 2 & Sedang \\
14. & Perancangan layout fitur konfirmasi logout & 2 & \\
15. & Perancangan layout fitur konfirmasi kelola & 2 & \\
& mahasiswa
\end{tabular}

\subsubsection{Daily Sprint}

Hasil dari sprint ke-2 yaitu rancangan layout. Hasil rancangan layout tersebut menjadi dasar untuk implementasi layout. Hasil rancangan layout pada sprint ke-2 dapat dilihat pada Gambar 3.
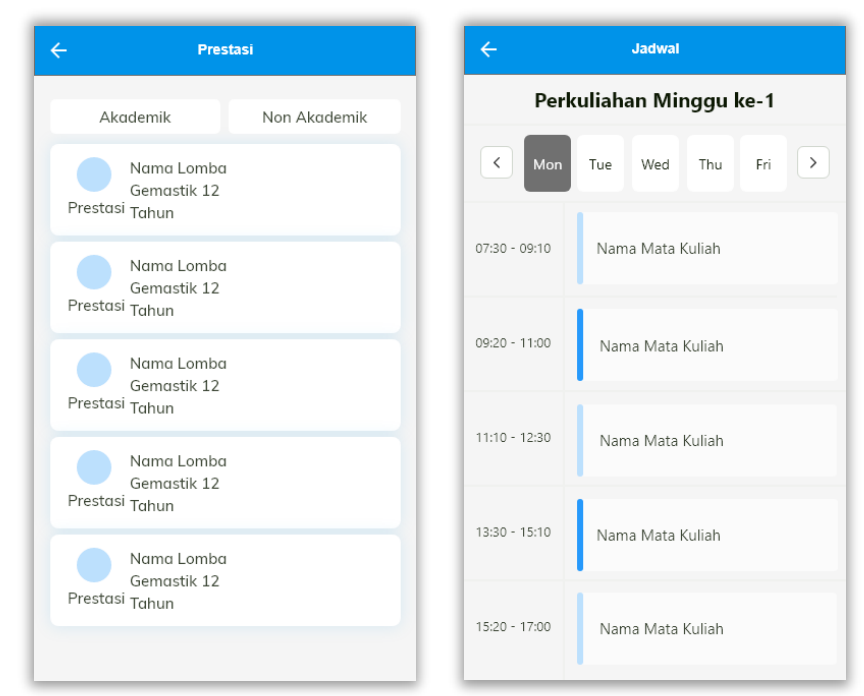

Gambar 3. Hasil Daily Sprint pada Sprint ke-2. 


\subsubsection{Sprint Review}

Hasil pengerjaan pada daily sprint dipresentasikan di hadapan tim scrum. Hasil dari sprint review yaitu terdapat saran yang diberikan oleh scrum master. Saran tersebut yaitu perbaikan beberapa elemen pada layout yang harus dihilangkan, diubah dan perlu penambahan elemen.

\subsubsection{Sprint Retrospective}

Pada tahap ini dilakukan perbaikan sesuai saran yang diberikan oleh scrum master.

\subsection{Sprint ke-3}

\subsubsection{Sprint Planning}

Sprint backlog ke-3 dapat dilihat pada Tabel 4.

Tabel 4. Sprint Backlog pada Sprint ke-3

\begin{tabular}{clcc}
\hline No. & Deskripsi & $\begin{array}{c}\text { Estimasi } \\
\text { (Jam) }\end{array}$ & $\begin{array}{c}\text { Tingkat } \\
\text { Kesulitan }\end{array}$ \\
\hline 1. & Implementasi rancangan layout & 30 & Tinggi \\
\hline
\end{tabular}

\subsubsection{Daily Sprint}

Tahap daily sprint yaitu mengimplementasikan layout sesuai dengan rancangan layout.

\subsubsection{Sprint Review}

Pada tahap ini peneliti mempresentasikan hasil pengerjaan pada sprint ke-3. Hasil sprint review yaitu semua pengerjaan sudah sesuai dengan yang diharapkan.

\subsubsection{Sprint Retrospective}

Tidak ada perbaikan yang harus diselesaikan peneliti pada sprint ke-3.

\subsection{Sprint ke-4}

\subsubsection{Sprint Planning}

Pada sprint ke-4, pengembangan sudah masuk ke tahap pengkodean. Hasil dari sprint planning yaitu sprint backlog yang dapat dilihat pada Tabel 5.

Tabel 5. Sprint Backlog pada Sprint ke-4

\begin{tabular}{clcc}
\hline No. & Deskripsi & $\begin{array}{c}\text { Estimasi } \\
\text { (Jam) }\end{array}$ & $\begin{array}{c}\text { Tingkat } \\
\text { Kesulitan }\end{array}$ \\
\hline 1. & Pengembangan fitur beranda & 6 & Sedang \\
2. & Pengembangan fitur intro dan splash screen & 10 & Tinggi \\
3. & Pengembangan fitur registrasi dan login & 20 & Tinggi \\
4. & Pengembangan fitur melihat daftar mahasiswa dan & 10 & Tinggi \\
& tambah mahasiswa & & \\
\hline
\end{tabular}




\subsubsection{Daily Sprint}

Pada sprint ke-4, daily sprint sudah masuk pada tahap pengembangan fitur sesuai dengan sprint backlog. Hasil dari sprint ke-4 dapat dilihat pada Gambar 4.

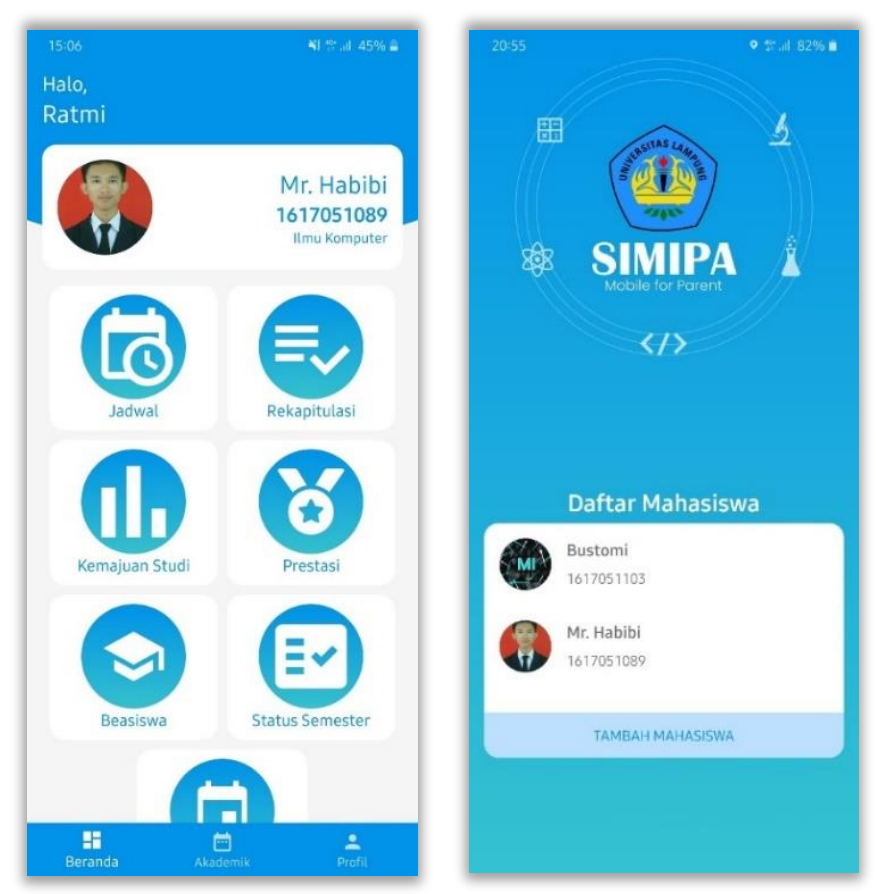

Gambar 4. Hasil Daily Sprint pada Sprint ke-4.

\subsubsection{Sprint Review}

Sprint review dilakukan dengan mempresentasikan hasil kerja selama sprint. Hasil dari sprint review yaitu pengerjaan sudah sesuai dengan yang diharapkan.

\subsubsection{Sprint Retrospective}

Semua pengerjaan pada sprint ke-4 sudah sesuai dengan yang diharapkan, sehingga tidak ada perbaikan pada sprint ke-4.

\subsection{Sprint ke-5}

\subsubsection{Sprint Planning}

Hasil dari sprint planning ke-5 yaitu sprint backlog. Sprint backlog tersebut dapat dilihat pada Tabel 6.

Tabel 6. Sprint Backlog pada Sprint ke-5

\begin{tabular}{clcc}
\hline No. & Deskripsi & $\begin{array}{c}\text { Estimasi } \\
\text { (Jam) }\end{array}$ & $\begin{array}{c}\text { Tingkat } \\
\text { Kesulitan }\end{array}$ \\
\hline 1. & Pengembangan fitur melihat jadwal & 16 & Tinggi \\
2. & Pengembangan fitur melihat profil mahasiswa & 7 & Sedang \\
\hline
\end{tabular}




\subsubsection{Daily Sprint}

Daily sprint pada sprint ke-5 yaitu pengembangan fitur melihat jadwal dan fitur melihat profil mahasiswa. Hasil dari daily sprint dapat dilihat pada Gambar 5.

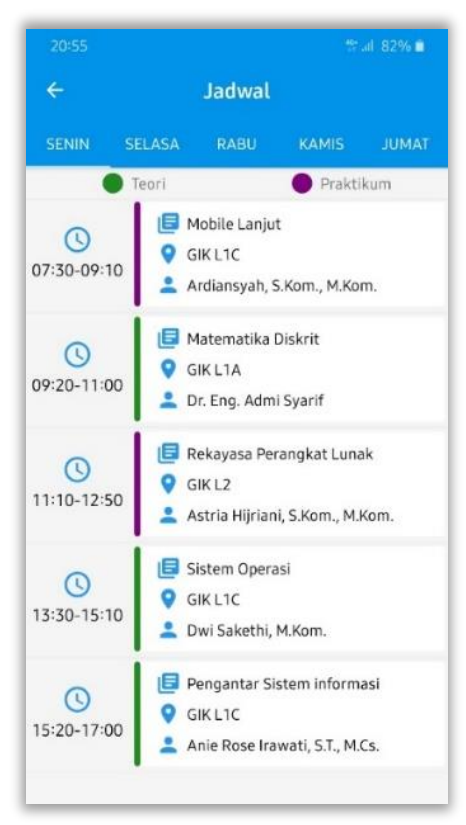

Gambar 5. Hasil Daily Sprint pada Sprint ke-5.

\subsubsection{Sprint Review}

Sprint review yaitu memeriksa hasil dari daily sprint ke-5. Hasil dari sprint review yaitu fitur yang dibuat sudah sesuai dengan yang diharapkan.

\subsubsection{Sprint Retrospective}

Tidak ada perbaikan pada sprint ke-5.

\subsection{Sprint ke-6}

\subsubsection{Sprint Planning}

Sprint backlog dari sprint planning ke-6 dapat dilihat pada Tabel 7.

Tabel 7.Sprint Backlog pada Sprint ke-6

\begin{tabular}{clcc}
\hline No. & Deskripsi & $\begin{array}{c}\text { Estimasi } \\
\text { (Jam) }\end{array}$ & $\begin{array}{c}\text { Tingkat } \\
\text { Kesulitan }\end{array}$ \\
\hline 1. & Pengembangan fitur melihat rekapitulasi seminar & 20 & Tinggi \\
2. & Pengembangan fitur melihat rekapitulasi & 15 & Tinggi \\
& bimbingan & 20 & Tinggi \\
\hline
\end{tabular}

\subsubsection{Daily Sprint}


Tahap daily sprint pada sprint ke-6 yaitu mengerjakan fitur melihat rekapitulasi seminar, fitur melihat rekapitulasi bimbingan dan melihat kemajuan studi. Hasil pengerjaan dapat dilihat pada Gambar 6.
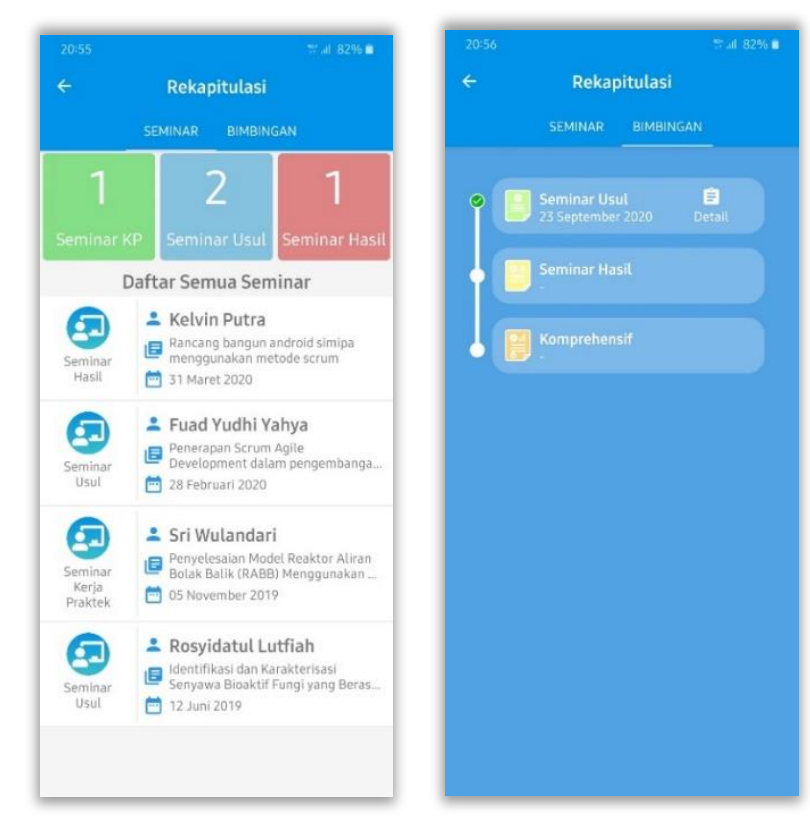

Gambar 6. Hasil Daily Sprint pada Sprint ke-6.

\subsubsection{Sprint Review}

Sprint review pada sprint ke-6 yaitu memeriksa hasil pengembangan fitur yang sudah dilakukan. Pada sprint review kali ini terdapat saran untuk memperbaiki fitur melihat rekapitulasi seminar. Saran tersebut yaitu membuat filter daftar seminar yang ditampilkan.

\subsubsection{Sprint Retrospective}

Sprint retrospective pada sprint ke-6 yaitu memperbaiki fitur rekapitulasi seminar sesuai dengan saran scrum master.

\subsection{Sprint ke-7}

\subsubsection{Sprint Planning}

Sprint backlog yang disetujui pada sprint ke-7 dapat dilihat pada Tabel 8.

Tabel 8. Sprint Backlog pada Sprint ke-7

\begin{tabular}{clcc}
\hline No. & Deskripsi & $\begin{array}{c}\text { Estimasi } \\
\text { (Jam) }\end{array}$ & $\begin{array}{c}\text { Tingkat } \\
\text { Kesulitan }\end{array}$ \\
\hline 1. & Pengembangan fitur melihat prestasi & 20 & Tinggi \\
2. & Pengembangan fitur melihat beasiswa & 10 & Tinggi \\
3. & Pengembangan fitur melihat status semester & 10 & Tinggi \\
4. & Pengembangan fitur logout & 25 & Tinggi \\
\hline
\end{tabular}




\subsubsection{Daily Sprint}

Daily sprint pada sprint ke-7 yaitu melakukan pengkodean untuk mengembangkan fitur yang terdapat pada sprint backlog. Hasil pengembangan fitur dapat dilihat pada Gambar 7.
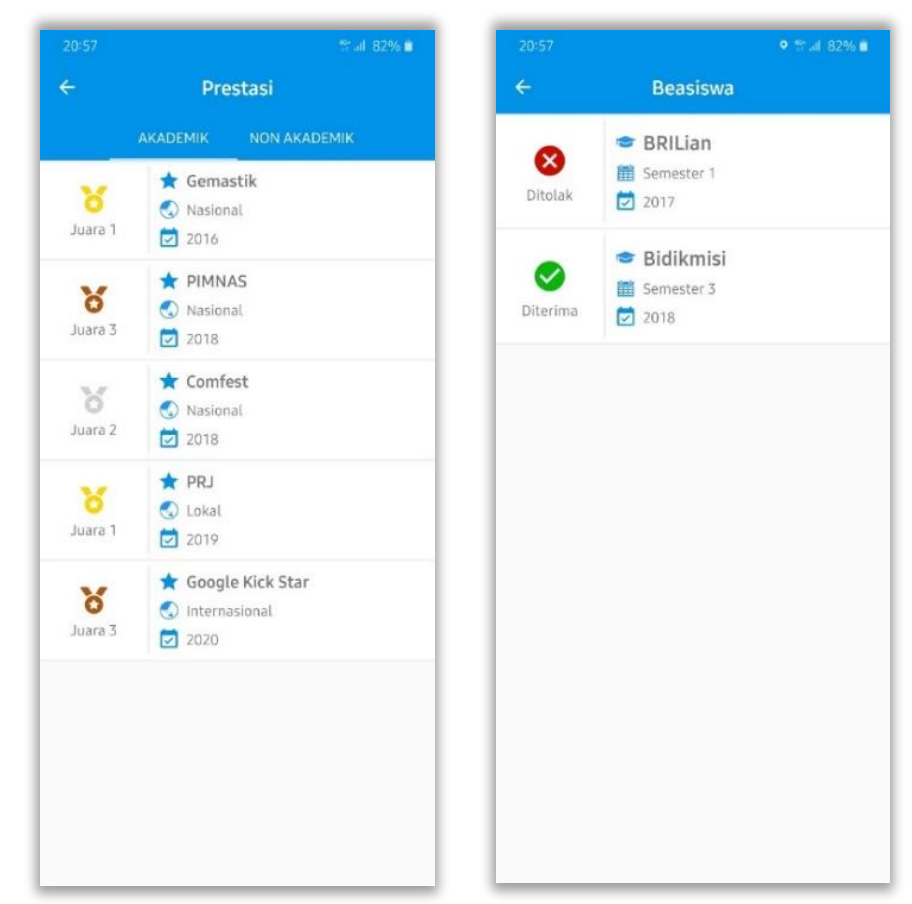

Gambar 7. Hasil Daily Sprint pada Sprint ke-7.

\subsubsection{Sprint Review}

Hasil dari sprint review yaitu pengembangan fitur pada sprint ke-7 sudah sesuai dengan yang diharapkan.

\subsubsection{Sprint Retrospective}

Disebabkan fitur yang dikembangkan pada sprint ke-7 sudah sesuai dengan yang diharapkan, sehingga tidak ada perbaikan pada sprint ke-7.

\subsection{Sprint ke-8}

\subsubsection{Sprint Planning}

Hasil dari sprint planning pada sprint ke-8 yaitu sprint backlog yang dapat dilihat pada Tabel 9.

Tabel 9. Sprint Backlog pada Sprint ke-8

\begin{tabular}{clcc}
\hline No. & Deskripsi & $\begin{array}{c}\text { Estimasi } \\
\text { (Jam) }\end{array}$ & $\begin{array}{c}\text { Tingkat } \\
\text { Kesulitan }\end{array}$ \\
\hline 1. & Pengembangan fitur melihat kalender akademik & 10 & Tinggi \\
2. & Pengembangan fitur melihat tanggal penting & 10 & Tinggi \\
3. & Pengembangan fitur melihat kelola mahasiswa & 20 & Tinggi
\end{tabular}




\subsubsection{Daily Sprint}

Daily sprint pada sprint ke-8 yaitu menyelesaikan sprint backlog ke-8. Hasil penyelesaian tersebut dapat dilihat pada Gambar 8.

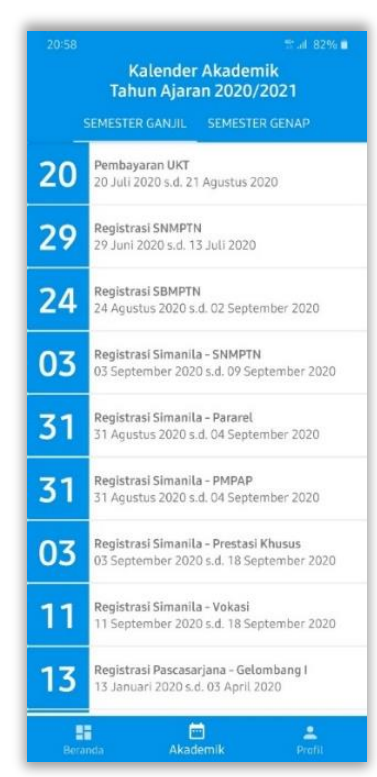

Gambar 8. Hasil Daily Sprint pada Sprint ke-8.

\subsubsection{Sprint Review}

Hasil sprint review yaitu pengerjaan sudah sesuai dengan yang diharapkan.

\subsubsection{Sprint Retrospective}

Tidak ada perbaikan pada sprint ke-8.

\subsection{Pengujian}

Pengujian pada penelitian ini menggunakan metode user acceptance testing (UAT) yang menguji tingkat kepuasan calon pengguna. Pengujian dilakukan terhadap 30 responden yang sudah menggunakan aplikasi SIMIPA Modul Orang Tua. Selanjutnya responden memberikan pendapat sesuai dengan kuesioner.

Terdapat 10 pernyataan pada kuesioner. Setiap pernyataan memiliki 5 kategori jawaban yang dapat dipilih oleh responden. Langkah pertama untuk menganalisis hasil pengujian yaitu menentukan interval penilaian skala likert. likert:

Berikut merupakan perhitungan untuk menentukan interval penilaian skala

$$
\mathrm{RS}=\frac{(\mathrm{m}-\mathrm{n})}{\mathrm{b}}
$$

Keterangan:

$$
\begin{array}{ll}
\mathrm{RS} & =\text { Rentang Skala } \\
\mathrm{m} & =\text { Angka tertinggi dalam pengukuran } \\
\mathrm{n} & =\text { Angka terendah dalam pengukuran } \\
\mathrm{b} & =\text { Banyaknya kelas atau kategori yang }
\end{array}
$$


$\mathrm{RS}=\frac{(5-1)}{5}=0.8$

Berdasarkan perhitungan tersebut, RS yang didapat adalah 0.8, sehingga dapat diketahui interval masing-masing kategori yang dapat dilihat pada Tabel 10.

Tabel 10. Interval Penilaian Skala Likert

\begin{tabular}{lcc}
\hline Kategori & Kode & Interval \\
\hline Sangat Tidak Memuaskan & STM & $1.0 \leq \mathrm{x}<1.8$ \\
Tidak Memuaskan & TM & $1.8 \leq \mathrm{x}<2.6$ \\
Netral & $\mathrm{N}$ & $2.6 \leq \mathrm{x}<3.4$ \\
Memuaskan & $\mathrm{M}$ & $3.4 \leq \mathrm{x}<4.2$ \\
Sangat Memuaskan & SM & $4.2 \leq \mathrm{x}<5.0$ \\
\hline
\end{tabular}

Langkah selanjutnya yaitu menghitung total nilai dari hasil pengujian. Total nilai didapat dari hasil penjumlahan nilai dari seluruh jawaban responden, untuk lebih jelas perhitungan total nilai menggunakan rumus berikut:

$$
\text { Total }=(\text { SM } \times 5)+(\text { M x })+(N \times 3)+(\text { TM x } 2)+(\text { STM } 1)
$$

Konstanta yang digunakan untuk mengalikan didapat dari nilai pada masingmasing kategori. Seluruh pertanyaan sudah mewakili tiga variabel uji yaitu usability quality, service interaction, dan information quality [10]. Hasil perhitungan dan rekapitulasi jawaban responden dapat dilihat pada Tabel 11.

Tabel 11. Rekapitulasi Hasil Pengujian

\begin{tabular}{|c|c|c|c|c|c|c|c|}
\hline No. & Pertanyaan & SM & $\mathbf{M}$ & $\mathbf{N}$ & TM & STM & Total \\
\hline 1. & $\begin{array}{l}\text { Aplikasi SIMIPA Modul Orang Tua mudah } \\
\text { untuk digunakan }\end{array}$ & 9 & 16 & 4 & 1 & 0 & 123 \\
\hline 2. & $\begin{array}{l}\text { Aplikasi SIMIPA Modul Orang Tua } \\
\text { memiliki tampilan yang menarik }\end{array}$ & 7 & 15 & 6 & 2 & 0 & 117 \\
\hline 3. & $\begin{array}{l}\text { Aplikasi SIMIPA Modul Orang Tua mudah } \\
\text { untuk dipahami }\end{array}$ & 7 & 17 & 4 & 2 & 0 & 119 \\
\hline 4 & $\begin{array}{l}\text { Saya nyaman menggunakan aplikasi } \\
\text { SIMIPA Modul Orang Tua }\end{array}$ & 8 & 13 & 8 & 1 & 0 & 118 \\
\hline 5. & $\begin{array}{l}\text { Melihat informasi perkuliahan } \\
\text { mahasiswa dapat dilakukan dengan } \\
\text { cepat dengan adanya aplikasi SIMIPA } \\
\text { Modul Orang Tua }\end{array}$ & 14 & 13 & 3 & 0 & 0 & 131 \\
\hline
\end{tabular}

Tabel 11. Rekapitulasi Hasil Pengujian (Lanjutan)

6. Pengguna merasa mudah menemukan informasi yang dicari

$\begin{array}{llllll}7 & 18 & 4 & 1 & 0 & 121\end{array}$

7. Informasi perkuliahan mahasiswa pada aplikasi SIMIPA Modul Orang Tua mudah untuk dimengerti 


\begin{tabular}{llllllll} 
8. $\begin{array}{l}\text { Aplikasi SIMIPA Modul Orang Tua dapat berjalan } \\
\text { dengan baik di smartphone saya }\end{array}$ & 17 & 9 & 4 & 0 & 0 & 133 \\
9. $\begin{array}{l}\text { Aplikasi SIMIPA Modul Orang Tua memberikan } \\
\text { informasi yang relevan }\end{array}$ & 11 & 16 & 3 & 0 & 0 & 128 \\
10. $\begin{array}{l}\text { Aplikasi SIMIPA Modul Orang Tua memberikan } \\
\text { informasi yang lengkap dan terperinci }\end{array}$ & 10 & 16 & 4 & 0 & 0 & 126 \\
\hline
\end{tabular}

Selanjutnya dapat dilakukan analisis data dengan mencari score yang akan digunakan untuk menginterpretasikan kategori dari setiap pernyataan. Score didapat dari total nilai dibagi jumlah responden. Setelah itu, setiap pernyataan diinterpretasikan menjadi kategori. Interpretasi didapat dari score dikonversikan pada tabel interval skala likert. Hasil perhitungan dapat dilihat pada Tabel 12.

Tabel 12. Perhitungan Tingkat Kepuasan Calon Pengguna

\begin{tabular}{clcc}
\hline No. & Pertanyaan & Score & Interpretasi \\
\hline 1. & Pernyataan 1 & 4.10 & Memuaskan \\
2. & Pernyataan 2 & 3.90 & Memuaskan \\
3. & Pernyataan 3 & 3.97 & Memuaskan \\
4. & Pernyataan 4 & 3.93 & Memuaskan \\
5. & Pernyataan 5 & 4.37 & Sangat Memuaskan \\
6. & Pernyataan 6 & 4.03 & Memuaskan \\
7. & Pernyataan 7 & 3.97 & Memuaskan \\
8. & Pernyataan 8 & 4.43 & Sangat Memuaskan \\
9. & Pernyataan 9 & 4.27 & Sangat Memuaskan \\
10. & Pernyataan 10 & 4.20 & Sangat Memuaskan \\
\hline
\end{tabular}

Tabel 12 menunjukkan bahwa aplikasi SIMIPA Modul Orang Tua sudah diterima oleh calon pengguna berdasarkan metode user acceptance testing (UAT).

\section{SIMPULAN}

Penelitian ini berhasil mengembangkan aplikasi SIMIPA Modul Orang Tua menggunakan metode scrum. Hasil pengujian menggunakan user acceptance testing (UAT) yaitu dari 10 pernyataan, pernyataan 5 , pernyataan 8 , pernyataan 9 , dan pernyataan 10 masuk dalam kategori sangat memuaskan dengan score berurutan yaitu $4.37,4.43,4.27$, dan 4.20 . Sedangkan, pernyataan 1 , pernyataan 2 , pernyataan 3 , pernyataan 4 , pernyataan 6 , dan pernyataan 7 masuk dalam kategori memuaskan dengan score berurutan yaitu 4.10, 3.90, 3.97, 3.93, 4.03, dan 4.20. Jika dirataratakan menghasilkan score 4.12, masuk dalam kategori memuaskan. Tidak ada pernyataan yang masuk dalam kategori sangat tidak memuaskan, kategori tidak memuaskan, maupun kategori netral. Hal tersebut menunjukkan bahwa aplikasi SIMIPA Modul Orang Tua sudah diterima oleh calon pengguna.

\section{DAFTAR PUSTAKA}

[1] K. V. Hoover-Dempsey and H. M. Sandler, "The Social Context of Parental Involvement: A Path to Enhanced Achievement", vol. 13, no. 2, pp. 100-108, 
2017.

[2] A. Setiawan, "Analisis Sistem Informasi Orang Tua Wali Mahasiswa berbasis Website Studi Kasus Universitas Muhammadiyah Magelang", Jurnal Informatika Upgris, vol. 2, no. 1, 2016.

[3] H. Indriyawati, "Analisis Sistem Informasi Akademik Berbasis Sms Gateway Pada Fakultas Teknologi Informasi Dan Komunikasi Universitas Semarang", Jurnal Transformatika, vol. 13, no. 1, p. 8, 2015.

[4] W. Y. Herpendi, "Aplikasi Monitoring Hasil Studi Mahasiswa Teknik Informatika Politeknik Negeri Tanah Laut Berbasis Web Mobile dan SMS Gateway", Seminar Nasional Informatika dan Aplikasinya (SNIA) 2017, no. September, pp. 68-74, 2017.

[5] We Are Social \& Hootsuite, "Digital 2020", Global Digital Insights, p. 247, 2020.

[6] P. A. G. Permana, "Scrum Method Implementation in a Software Development Project Management", International Journal of Advanced Computer Science and Applications, vol. 6, no. 9, pp. 198-204, 2015.

[7] A. C. Fatiyah, S. F. S. Gumilang, and D. Witarsyah, "Pengujian Fungsional dan Non Fungsional Aplikasi Web Borongajayuk", e-Proceeding of Engineering, vol. 6, no. 2, pp. 8415-8421, 2019.

[8] J. Sutherland, "Jeff Sutherland's Scrum handbook", May. 2010.

[9] G. Booch, J. Rumbaugh, I. Jacobson, and A. Wesley, "The Unified Modeling Language User Guide", The Library of Congress Cataloging-in-Publication Data. Addison-Wesley Longman Inc., 1998.

[10] L. Ari, S. Suhandiah, and Sulistiowati, "Analisis Pengaruh Kualitas Website Terhadap Kepuasan Pengguna Berdasarkan Metode Webqual 4.0 Pada Website SMAN 2 Kota Mojokerto", Jsika, vol. 5, no. 11, pp. 1-14, 2016. 